\title{
Deteksi Tipe Modulasi Digital Pada Automatic Modulation Recognition Menggunakan Support Vector Machine dan Conjugate Gradient Polak Ribiere-Backpropagation
}

\author{
Ni Luh Komang Tri Wahyuni M.U ${ }^{1}$, I Made Oka Widyantara ${ }^{2}$, Ni Made Ary Esta Dewi $\mathrm{W}^{3}$
}

[Submission: 13-06-2019, Accepted:22-08-2019]

\begin{abstract}
The rapid development of wireless technology is currently inseparable from the continued development of flexible platform designs, one of which is being able to classify the modulation scheme of the detected signal. In the discussion related to the AMR system continues to be developed. In this paper a simulation of a digital modulation type detection system is carried out with a QPSK, 16-QAM and 64-QAM modulation scheme. The data used in this simulation is Non Return to Zero (NRZ) unipolar with a 0 volt and 1 volt amplitude. This randomly generated data is simulated through a fading canal extracted to obtain characteristic signal using statistical approach. These characteristic will be selected to determine the best characteristic using the Multi Class Support Vector Machine $(S V M)$ method. From the results of this simulation in the introduction of the modulation type scheme using the Conjugate Gradient Polak Ribiere-Backpropagation method able to classify the modulation type with learning efficiency much better after comparison with the Gradient Discent method, this is indicated by the regression value on Conjugate Gradient Polak Ribiere > regression value on Gradient Discent.
\end{abstract}

Intisari- Pesatnya perkembangan teknologi nirkabel saat ini tidak lepas dari terus dikembangkannya sebuah desain platform yang fleksibel salah satunya adalah mampu melakukan klasifikasi skema modulasi dari sinyal terdeteksi. Dewasa ini pembahasan terkait dengan sistem AMR terus dikembangkan. Pada Paper ini dilakukan simulasi sistem deteksi tipe modulasi digital dengan skema modulasi QPSK, 16-QAM dan 64-QAM. Data yang digunakan dalam simulasi ini adalah data Non Return to Zero (NRZ) unipolar dengan amplitudo 0 volt dan 1 volt. Data yang yang dibangkitkan secara random ini disimulasikan melewati kanal fading yang kemudian diekstrasi untuk mendapatkan karakteristik sinyal dengan menggunakan pendekatan statistik. karakteristik inilah yang kemudian akan di seleksi untuk menentukan karakteristik terbaik dengan metode Multi Class Support Vector Machine (SVM). Dari hasil simulasi ini dalam pengenalan skema tipe modulasi dengan menggunakan metode Conjugate Gradient Polak Ribiere-Backpropagation mampu melakukan klasifikasi tipe modulasi dengan efisiensi pembelajaran jauh lebih baik setelah dilakukan komparasi dengan metode Gradient Discent, hal ini ditunjukkan dengan nilai regresi pada Conjugate Gradient Polak Ribiere > dari nilai regresi pada Gradient Discent.

Kata Kunci-Non Return to Zero, Statistik, Multi Class Support Vector Machine, Backpropagation, Conjugate Gradient Polak Ribiere, Gradient Discent

\footnotetext{
${ }^{1}$ Mahasiswa, Magister Teknik Elektro, Program Pasca Sarjana Universitas Udayana (e-mail: komangtri1945@gmail.com)

${ }^{2,3}$ Staff pengajar Magister Teknik Elektro, Program Pasca Sarjana Universitas Udayana, Jl. PB.Sudirman Denpasar (telp: 0361-703315; fax: ); e-mail: oka.widyantara@unud.ac.id dewi.wirastuti@unud.ac.id ${ }^{3}$
}

\section{PENDAHULUAN}

Membahas tentang perkembangan teknologi komunikasi saat ini khususnya dalam komunikasi nirkabel, maka perlu dibahas pula proses transmisi data dari transmitter (pengirim) ke receiver (penerima) hingga informasi dapat diterima dengan baik.

Kondisi ini membutuhkan suatu desain yang ideal dengan platform yang fleksibel dengan user interface tunggal untuk prototype standar nirkabel yang berbeda-beda. Hal inilah yang mendasari adanya konsep radio yang didefinisikan sebagai software, yaitu Software Defined Radio (SDR). Dengan menerapkan fungsi-fungsi yang ada dalam software maka receiver yang digunakan pada system tersebut akan mampu menerima semua skema modulasi tanpa harus merubah perangkat fisiknya. Inilah solusi yang potensial untuk jaringan yang fleksibel, dinamis dan rendahnya biaya operasional. Automatic Modulation Recognition (AMR) yang merupakan bagian dari SDR ini dibagi menjadi dua blok yaitu blok sinyal dan blok klasifikasi. Pada blok prosesing mencakup tentang estimasi power sinyal, SNR, real time, frekuensi, dll sedangkan blok klasifikasi algoritma menyesuaikan dengan akurasi sinyal prosesing sebelumnya, tergantung pada kompleksitas AMR yaitu real time atau off-line [1].

Dewasa ini mulai berkembang penelitian yang terkait tentang AMR. Algoritma Support Vector Machine (SVM) dengan konfigurasi kernel dengan menggunakan Particale Swarm Optimation (PSO) merupakan salah metode yang baik digunakan dalam klasifikasi tipe modulasi dengan skema modulasi FSK, PSK, ASK dan QAM. Adapun ekstrasi ciri yang digunakan dalam penelitian tersebuta adalah spectral, statistik dan wavelet, metode yang di gunakan ini tahan terhadap niose dengan menggunakan data SNR yang rendah [2]. Penelitian serupa juga telah dilakukan dengan menggunakan skema modulasi QPSK, 16-QAM dan 64-QAM yang melewati kanal Fanding dan AWGN, sedangkan untuk ekstrasi ciri modulasi hanya menggunakan statistik juga mampu menghasilkan tingkat akurasi klasifikasi yang baik [3]. Backpropagation juga memiliki kemampuan yang baik dalam mengklasifikasi tipe modulasi dengan menggunakan seleksi ciri sinyal termodulasi dengan menggunakan Algoritma Genetika dan ekstrasi ciri memanfaatkan spectral dan statistik, sedangkan skema modulasi yang digunakan adalah QPSK, 16QAM dan 64-QAM [4].

Berdasarkan paparan diatas, maka dalam paper ini menggunakan metode Conjugate Gradient Polak RibiereBackpropagation dalam klasifikasi tipe modulasi dengan Support Vector Machine pada seleksi ciri dan Statistik pada ekstrasi ciri.

N1 Luh Komang Ir1 Wahyunı M.U: Deteks1 Iipe Modulası Digital .... 


\section{LANDASAN TEORI}

Deteksi tipe modulasi pada AMR yang menggunakan Support Vector Machine dan Conjugate Gradient Polak Ribiere-Backpropagation pada paper ini paparkan dalam kerangka kerja sebagai berikut:

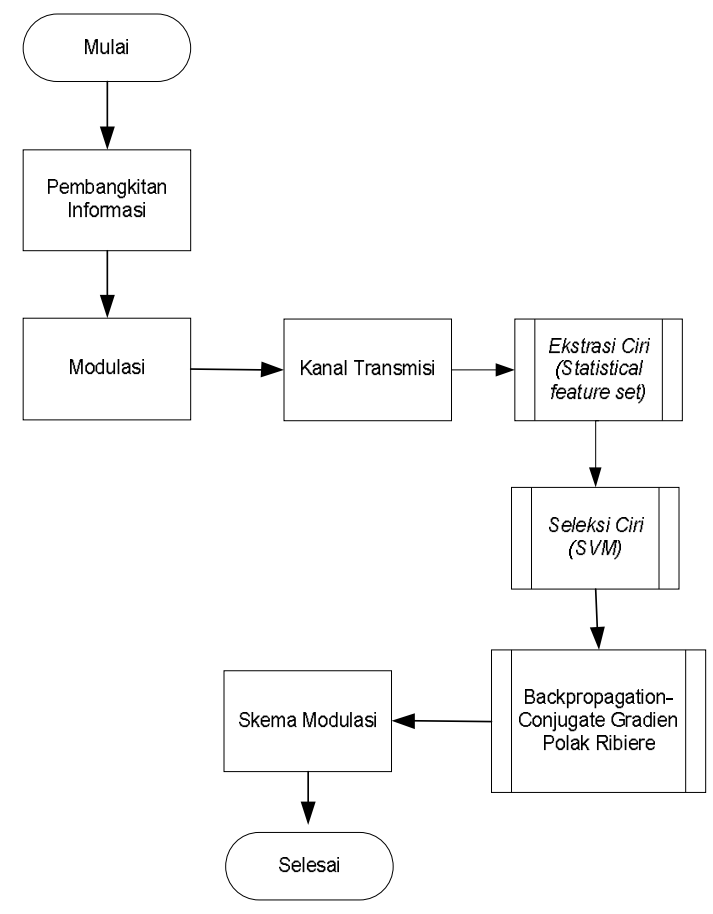

Gambar 1: Gambar Kerangka Penelitian

Pada kerangka diatas tahap Generate Information diatas sinyal yang di bangkitkan secara random yang kemudian akan termodulasi oleh skema modulasi QPSK, 16-QAM dan 64QAM. Sinyal termodulasi tersebut akan melewati kanal transmisi, dalam hal ini adalah menggunakan kanal fading. Sinyat termodulas tersebut kemuian dilakukan proses ekstrasi ciri (Feature Extraction) dengan menggunakan pendekatan statistik (Statistical Feature Set) dan Seleksi ciri untuk mendapatkan fitur terbaik dengan menggunakan Support Vector Machine (SVM).

Untuk menentukan tipe modulasi yang sesuai pada skema modulasi, maka pada klasifikasi menggunakan Backpropagation.

\section{A. Ekstrasi Ciri (Statistical Feature Set)}

Ekstrasi ciri merupakan suatu proses mendapatkan karakteristik/ciri dari sinyal. Dalam mendapatkan nilai ciri dari sinyal termodulasi tersebut menggunakan pendekatan statistik (statistical featur set) dengan empat metode diantaranya adalah sebagai berikut:

1) Mean : Mean merupakan nilai rata-rata dari beberapa data yang diperoleh dengan rumus sebagai berikut:

Mean $=\mathrm{x}=\frac{\sum_{\mathrm{i}=1}^{N} x_{i}}{N}$

2) Varian : Varian merupakan mean dari kuadrat simpang, yang dapat dihitung dengan rumus sebagai berikut:

Varian $=$ rata-rata $\left(x_{i}-x\right)^{2}=\frac{\sum_{\mathrm{i}=1}^{N}\left(x_{i}-x\right)^{2}}{N}$
3) Skewness: Skewness merupakn derajat kesimetrisan dari suatu distribusi nilai, yang di hitung denangan rumus berikut:

Skewness $=\frac{1}{N \sigma^{3}} \sum_{i=1}^{N}\left(x_{i}-\mu\right)^{3}$

4) Kurtosis:Kurtosis adalah derajat keruncingan suatu distribusi nilai, yang di hitung dengan rumus sebagai berikut:

Kurtosis $=\frac{1}{N \sigma^{4}} \sum_{i=1}^{N}\left(x_{i}-\mu\right)^{4}$

\section{B. Support Vector Machine (SVM)}

Support Vector Machine (SVM) dikembangkan oleh Boser, Guyon dan Vapnik. Metode ini pertama kali di presentasikan pada tahun 1992 di Annual Workshop on Computational Learning Theory. Secara umum konsep klasifikasi dengan SVM adalah sebagai usaha mencari hyperplane terbaik yang berfungsi sebagai pemisah dua buah kelas data pada input space. SVM memiliki beberapa keunggulan, diantaranya adalah mampu mengatasi masalah klasifikasi dan regresi dengan linier maupun non linier, memiliki akurasi tinggi dan tingkat kesalahan yang relative kecil, memiliki kemampuan untuk overfitting dangan tanpa membutuhkan data yang terlalu besar dan dapat digunakan untuk melakukan prediksi. Namun kelemahan SVM adalah sulit menentukan nilai parameter yang optimal [5].

Dewasa ini SVM telah berhasil diaplikasikan pada beberapa permasalahan non-linear dengan cara memasukkan konsep kernel trick pada ruang kerja berdimensi tinggi. Penelitian tentang SVM Multi Class ini terus dikembangkan sehingga bisa memecahkan permasalahan multi-class dengan baik, karena permasalahan dalam aplikasi praktis cenderung melibatkan permasalahan multi class.

\section{Multi Class Support Vector Machine (SVM)}

Ada dua pilihan untuk mengimplementasikan multi-class $S V M$, yaitu dengan menggabungkan beberapa SVM biner atau menggabungkan semua data yang terdiri dari beberapa class kedalam bentuk optimasi [6]. Beberapa pendekatan/strategi yang dapat diterapkan untuk mengatasi masalah Error Corecting Output Code (ECOC) diantaranya adalah OneVersus-Rest (1VR) dan One-Versus-One(1VI).

Dalam penelitian ini pendekatan yang digunakan adalah pendekatan 1V1 yang dikenal juga sebagai strategi dekomposisi berpasangan, dimana dalam pendekatan ini semua classifiers yang mungkin berpasangan. Setiap classifier diterapkan ke data uji yang akan memberikan satu nilai untuk class pemenang. 


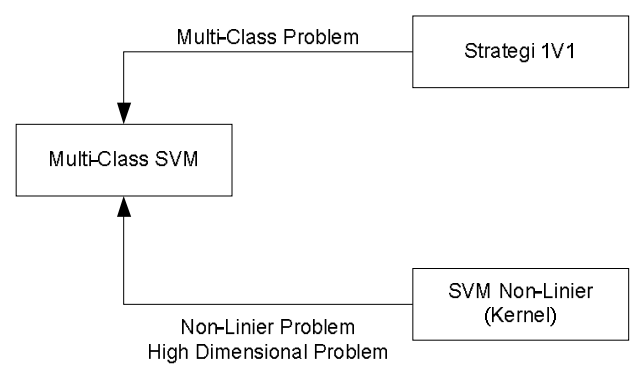

Gambar 2: Gambar kerangka kerja Multi-Class SVM.[7]

\section{Conjugate Gradient Polak Ribiere}

Conjugate Gradient merupakan metode optimasi yang dapat meminimasi suatu fungsi, dimana arah pencariannya berdasarkan arah konjugasi yang nilainya ortogonal. Karena sifat pencariannya yang ortogonal, sehingga Conjugate Gradient cepat mencapai konvergensi pada solusi yang dicari. Conjugate Gradient tidak hanya dapat digunakan untuk menyelesaikan fungsi linier, tapi juga dapat digunakan untuk masalah non linier, seperti design enginering, pelatihan jaringan syaraf tiruan, financial time series forcasting, dan regresi non linier [8]. Polak Ribiere merupakan salah satu jenis metode Conjugate Gradient yang paling sering direkomendasikan karena memiliki kemampuan numerik yang sangan baik [9].

\section{E. Algoritma Conjugate Gradient Polak Ribiere dalam pelatihan Backpropagation}

Langkah awal sebelum Conjugate Gradient digabungkan dalam pelatihan Backpropagation adalah menentukan terlebih dahulu ditentukan fungsi objektif yang akan dioptimalisasi. Adapun tujuannya adalah meminimalisasi error yang bergantung pada bobot-bobot yang menghubungkan antar neuron.Fungsi error yang digunakan adalah [10] :

$\mathrm{f}(\mathrm{w})=\frac{1}{2 N} \Sigma_{\mathrm{n}} \Sigma_{\mathrm{j}}\left(\mathrm{t}_{\mathrm{nj}}-\mathrm{y}_{\mathrm{nj}}(\mathrm{w})\right)^{2}$

dimana :

$\mathrm{N}=$ jumlah pola pada data training

$\mathrm{W}=$ matrik bobot

$\mathrm{T}_{\mathrm{nj}}$ dan $\mathrm{y}_{\mathrm{nj}}=$ data target dan output neuron untuk $\mathrm{n}$ pola.

Conjugate Gradient merupakan metode untuk meminimalisasi fungsi turunan dengan menghitungnpendekatan $\mathrm{w}_{\mathrm{k}+1}$ secara interaktive berdasarkan:

$\mathrm{W}_{\mathrm{k}+1}=\mathrm{w}_{\mathrm{k}}+\alpha_{\mathrm{k}} \mathrm{d}_{\mathrm{k}}$

$\mathrm{d}_{\mathrm{k}+1}=-\mathrm{g}_{\mathrm{k}+1}+\beta_{\mathrm{k}} \mathrm{d}_{\mathrm{k}}$

dimana: $\alpha$ dan $\beta$ adalah parameter momentum untuk menghindari konvergensi lokal.

Algoritma Conjugate Gradient Polak Ribiere sebagai pelatihan Backpropagation adalah sebagai berikut:

1. Inisialisasi semua bobot dengan bilangan acak.

2. Jika kondisi penghentian belum terpenuhi, lakukan langkah 1-4

3. Propagasi Maju dilakukan dengan tahapan sebagai berikut:

- Setiap unit masukan menerima sinyal dan meneruskannya ke unit tersembunyi diatasnya.
- Hitung semua keluaran di unit-unit tersembunyi $\mathrm{z}_{j}$ $(\mathrm{j}=1,2,3, . . p)$

$\mathrm{Z} \_n e t_{\mathrm{j}}=\mathrm{v}_{\mathrm{j} 0}+\sum_{i=1}^{n} x_{i} v_{j i}$

$\mathrm{Z}_{\mathrm{j}}=\mathrm{f}\left(\mathrm{z} \_\right.$net $\left.\mathrm{j}_{\mathrm{j}}\right)=\frac{1}{1+e^{-\mathrm{z}_{-} n e t_{j}}}$

- Hitung semua keluaran di unit output yk $(\mathrm{k}=1,2,3, \ldots \mathrm{p})$

$\mathrm{y} \_n e t_{\mathrm{j}}=\mathrm{w}_{\mathrm{k} 0}+\sum_{j=1}^{p} z_{i} w_{k j}$

$$
\mathrm{y}_{\mathrm{k}}=\mathrm{f}\left(\mathrm{y} \_n e \mathrm{t}_{\mathrm{k}}\right)=\frac{1}{1+e^{-y \_n e t_{k}}}
$$

4. Propagasi Mundur dilakukan dengan tahapan sebagai berikut:

- Hitung faktor kesalahannya di unit output berdasarkan perbedaan (error) nilai aktual dan nilai prediksi (output dari unit output)

$\delta_{\mathrm{k}}=\left(\mathrm{t}_{\mathrm{k}}-\mathrm{y}_{\mathrm{k}}\right) \mathrm{f}^{\prime}\left(y_{\text {net }_{k}}\right)$

$\delta_{\mathrm{k}}=\left(\mathrm{t}_{\mathrm{k}}-\mathrm{y}_{\mathrm{k}}\right) \mathrm{y}_{\mathrm{k}}\left(1-y_{\mathrm{k}}\right)$

- Hitung faktor kesalahan di unit tersembunyi berdasarkan faktor kesalahan pada unit di atasnya.

$\delta$ net $_{\mathrm{j}}=\sum_{k=1}^{m} \delta_{k} w_{k j}$

$\delta_{\mathrm{j}}=\delta_{n e t_{j}} \mathrm{f}^{\prime}\left(z_{n e t_{j}}\right)$

$\delta_{\mathrm{j}}=\delta$ net $_{\mathrm{j}} \mathrm{z}_{\mathrm{j}}\left(1-\mathrm{z}_{\mathrm{j}}\right)$

- Hitung gradient di unit output dari fungsi objektif yang sudah di tentukan

$$
\mathrm{g}_{\mathrm{k}+1}=\frac{1}{N} \sum_{n=1}^{p} \delta_{n k} y_{n k}
$$

- Hitung gradient di unit tersembunyi

$\mathrm{G}_{\mathrm{j}+1}=\frac{1}{N} \sum_{n=1}^{p} \delta_{n j} z_{n j}$

- Hitung parameter $\beta$ untuk semua neuron di unit tersembunyi dan unit output, untuk Conjugate Gradient Polak Ribiere persamaannya adalah sebagai berikut:

$\beta_{\mathrm{t}+1}=\frac{g_{t+1}^{T}\left(g_{t+1}-g_{t}\right)}{g_{t}^{T} g_{t}}$

- Hitung direction untuk semua neuron di unit tersembunyi dan unit output.

$\mathrm{d}_{\mathrm{t}+1}=-\mathrm{g}_{\mathrm{t}+1}+\beta_{\mathrm{t}} \mathrm{d}_{\mathrm{t}}$

Untuk direction awal :

$\mathrm{d}_{1}=-\mathrm{g}_{1}$

- Hitung parameter $\alpha$ untuk semua neuron di unit tersembunyi dan unit output yang merupakan seberapa besar langkah yang diambil untuk setiap direction. Parameter ini dapat dicari dengan teknik line search.

- Update bobot dilakukan dengan cara sebagai berikut:

$\mathrm{W}_{\mathrm{t}+1}=\mathrm{W}_{\mathrm{t}}+\alpha_{\mathrm{t}+1}+\mathrm{d}_{\mathrm{t}+1}$

Ni Luh Komang Tri Wahyuni M.U: Deteksi Tipe Modulasi Digital ....

\section{METODOLOGI PENELITIAN}


Secara umum sistem deteksi tipe modulasi terbagi menjadi 3 blok besar yaitu blok pengirim (transmitter), blok kanal transmisi dan blok penerima (recaiver). Mengacu pada Gambar 1, yang tergolong dalam blok transmiter adalah sub blok pembangkitan informasi dan modulasi, sedangkan yang tergolong dalam blok receiver adalah sub blok ekstrasi ciri (statistical featur set), seleksi ciri (SVM), Conjugate Gradien Polak Ribiere-Backpropagation dan skema modulasi.

\section{A. Pembangkitan Informasi}

Pada simulasi ini data yang digunakan adalah data digital dengan menggunakan data Non Return to Zero (NRZ) unipolar dengan amplitudo 1 volt untuk bit '1' dan 0 volt untuk bit '0'. Dengan parameter adalah sebagai berikut:

1. Panjang bit $=9600$ bit.

2. Periode 1 detik setiap kali mengirim sinyal

3. Bitrate $=9,6 \mathrm{kbps}$

4. Sinyal dibangkitkan bernilai random

B. Modulasi

Skema modulasi yang dipilih adalah skema tipe modulasi yang pada sistem WiMax 802.16x yaitu QPSK, 16-QAM dan 64-QAM.

\section{Kanal Transmisi}

Sinyal termodulasi yang di hasilkan dari blok transmitter kemudian akan melewati kanal transmisi dan mengalami respon kanal. Adapun kanal yang digunakan dalam paper ini adalah kanal fading.

\section{Featur Extraction (Ekstrasi Ciri)}

Setelah mendapatkan nilai amplitudonya, nilai tersebuat kemudian diproses untuk mendapatkan ekstrasi ciri/ karakteristik sinyalnya dengan pendekatan statistik (statistical featur set) yaitu dengan metode mean, varian, kurtosis dan skewness.

\section{E. Feature Selection (Seleksi Ciri) dengan Support Vector Machine (SVM)}

Hasil dari ekstrasi ciri kemudian akan di lakukan proses Feature Selection (seleksi ciri) dengan menggunakan metode Multi Class SVM.

TABEL 1

CLASS EKSPERIMEN

\begin{tabular}{|c|c|l|}
\hline Opsi & Kode & Keterangan \\
\hline 1 & 1 & Bukan Fitur \\
\hline 2 & 2 & Mean \\
\hline 3 & 3 & Varian \\
\hline 4 & 4 & Kurtosis \\
\hline 5 & 5 & Skewness \\
\hline
\end{tabular}

Dalam proses klasifikasi pengkodean yang digunakan adalah ClassificationECOC (Error Corecting Output Code), dimana pengkodean ini sangat mendukung proses klasifikasi untuk Multi Class SVM, sehingga memiliki kemampuan untuk memprediksi probabilitas posterior untuk data baru. Parameter yang digunakan dalam Support Vector Machine $(S V M)$ ini diantaranya adalah:
1. Pendekatan Kernel yang digunakan pada awal fitur data set adalah Linier.

2. Strategi yang digunakan dalam mengatasi masalah ECOC adalah $1 \mathrm{~V} 1$.

Untuk mendapatkan nilai terbaik dari score yang ada maka dalam penelitian ini menggunakan fungsi mode() pada mathlab. Nilai score terbaik untuk masing-masing class inilah yang nantinya akan dijadikan nilai input pada Backpropagation.

\section{F. Klasifikasi dengan Conjugate Gradient Polak Ribibere - Backpropagation}

Dalam implementasi Jaringan Syaraf Tiruan (JST) Backpropagation terdapat 2 proses utama, yaitu pelatihan/pembelajaran dan pengujian. Dari proses pembelajran dengan data latih diperoleh arsitektur jaringan seperti pada Gambar 3 dibawah ini, yaitu 5 node pada layer input, 2 hidden layer dengan masing-masing later terdiri dari 25 node dan 3 node pada layer output.

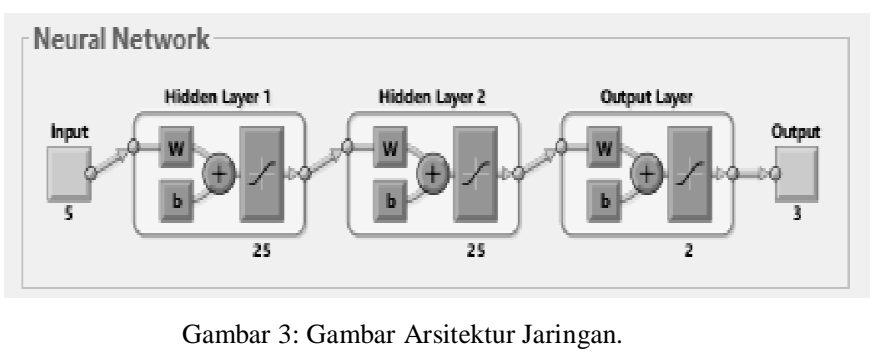

Pada layer output akan menghasilkan pasangan target yang sesuai dengan Tabel 2 di bawah ini,

TABEL 2

INISIALISASI TARGET PELATIHAN JARINGAN

\begin{tabular}{|c|c|}
\hline Tipe Modulasi & Target JST \\
\hline QPSK & 001 \\
\hline 16-QAM & 010 \\
\hline 64-QAM & 011 \\
\hline
\end{tabular}

Namun bila pada layer output menghasilkan pasangan target yang tidak dikenal pada Tabel 2 maka jaringan tidak mampu mengenal tipe modulasi yang dihasilkan oleh jaringan.

Pada proses pengujian dilakukan pengukuran kinerja sistem yang dihitung berdasarkan pada modulasi error detection sesuai dengan persamaan berikut:

Akurasi $=\frac{\text { pola deteksi benar }}{\text { jumlah pola deteksi }} \times 100 \%$

Laju Error $=\frac{\text { Pola deteksi salah }}{\text { jumlah pola deteksi }} \times 100 \%$

\section{HASIL DAN PEMBAHASAN}

\section{A. Analisa Ekstrasi Ciri Sinyal Termodulasi.}

Dari keempat ciri yang telah ditetapkan yaitu mean, varian, kurtosis dan skewness ini kemudian diklasifikasikan menjadi 2 kelompok berdasarkan tipe modulasi yang digunakan yaitu 
mudah mengenali tipe modulasi atau susah mengenali tipe modulasi.

Mudah mengenali tipe modulasi karena nilai hasil ekstrasi ciri mengelompok berdasarkan tipe modulasi tertentu, sedangkan klasifikasi untuk susah mengenali tipe modulasi apabila nilai hasil ekstrasi ciri relatif menyebar dan adanya kecenderungan untuk memiliki nilai hasil ekstrasi ciri yang serupa/ berdekatan.Untuk setiap ciri tersebut akan dilakukan ekstrasi pada kondisi SNR dari 0-10dB.

\section{B. Analisa Seleksi Ciri Sinyal Termodulasi.}

Seleksi ciri dilakukan dengan menggunakan metode Multi Class SVM dengan nilai diperoleh dari nilai Score. Karena terdapat 5 class klasifikasi pada SVM ini maka diperoleh 25 nilai score, sesuai dengan matrik 5x5. Nilai-nilai score terbaik untuk masing-masing kelas inilah yang nantinya akan diambil untuk menjadi data input pada Backpropagation.

\section{Analisis Kinerja Backpropagation-Konjugate Gradient Polak Ribiere untuk klasifikasi tipe modulasi}

Analisa terhadap kinerja klasifikasi tipe modulasi dilakukan dengan dua tahapan diantaranya adalah :

1) Analisis Kinerja Tahap Pelatihan:

Pada tahap pelatihan ini akan dianalisa jumlah data benar selama pelatihan, jumlah data salah selama pelatihan, Akurasi, Laju Error dan Regresi. Data dari hasil pelatihan dengan menggunakan metode Gradient Polak Ribiere kemudian akan dibandingkan dengan metode Gradient Discent untuk mengetahui kinerja pelatihannya.

Parmeter yang digunakan dalam proses Pelatihan untuk kedua metode tersebut adalah sebagai berikut:

1. Performasi yang digunakan adalah $\mathrm{MSE}=10^{-6}$.

2. Maksimum eppoch bernilai 1000 .

3. Learning:

- Untuk metode Gradient Plak Ribiere:

$\alpha=0,01 ; \beta=0,1 ; \Delta=0,01$.

Dimana : $\alpha$ dan $\beta$ adalah skala perhitungan untuk menghindari konvergensi lokal, sedangkan $\Delta$ adalah interval learning.

- Untuk metode Gradient Discent:

Learning Rate $(\alpha)=0,01$.

Hasil pelatihan untu kedua metode pembelajaran pada backpropagation dengan pelatihan sebanyak 200 kali dapat di lihat pada Tabel 3 dan Tabel 4 berikut.

TABEL 3

HASIL PELATIHAN DENGAN GRADIENT POLAK RIBIERE

\begin{tabular}{|c|c|c|c|c|}
\hline \multirow{2}{*}{$\begin{array}{c}\text { Training } \\
\text { Ke- }\end{array}$} & \multicolumn{4}{|c|}{ Gradient Polak Ribiere } \\
\hline & $\begin{array}{l}\text { Jml Data } \\
\text { Benar }\end{array}$ & $\begin{array}{l}\text { Jml Data } \\
\text { Salah }\end{array}$ & Akurasi & $\begin{array}{c}\text { Laju } \\
\text { Error }\end{array}$ \\
\hline 3 & 295 & 106 & $73,57 \%$ & $26,43 \%$ \\
\hline 50 & 293 & 108 & $73,07 \%$ & $26,93 \%$ \\
\hline 100 & 290 & 111 & $72,32 \%$ & $27,68 \%$ \\
\hline 125 & 293 & 108 & $73,07 \%$ & $26,93 \%$ \\
\hline 150 & 293 & 108 & $73,07 \%$ & $26,93 \%$ \\
\hline 175 & 293 & 108 & $73,07 \%$ & $26,93 \%$ \\
\hline 200 & 336 & 65 & $83,79 \%$ & $16,21 \%$ \\
\hline
\end{tabular}

Ni Luh Komang Tri Wahyuni M.U: Deteksi Tipe Modulasi Digital ....
TABEL 4

HASIL PELATIHAN DENGAN GRADIENT DISCENT

\begin{tabular}{|c|c|c|c|c|}
\hline \multirow{2}{*}{$\begin{array}{c}\text { Training } \\
\text { Ke- }\end{array}$} & $\begin{array}{c}\text { Jml } \\
\text { Data } \\
\text { Benar }\end{array}$ & $\begin{array}{c}\text { Jml Data } \\
\text { Salah }\end{array}$ & Akurasi & $\begin{array}{c}\text { Laju } \\
\text { Error }\end{array}$ \\
\hline 3 & 245 & 156 & $61,10 \%$ & $38,90 \%$ \\
\hline 50 & 261 & 140 & $65,09 \%$ & $34,91 \%$ \\
\hline 100 & 264 & 137 & $65,84 \%$ & $34,16 \%$ \\
\hline 125 & 271 & 130 & $67,58 \%$ & $32,42 \%$ \\
\hline 150 & 271 & 130 & $67,58 \%$ & $32,42 \%$ \\
\hline 175 & 274 & 127 & $68,33 \%$ & $31,67 \%$ \\
\hline 200 & 277 & 124 & $69,08 \%$ & $30,92 \%$ \\
\hline
\end{tabular}
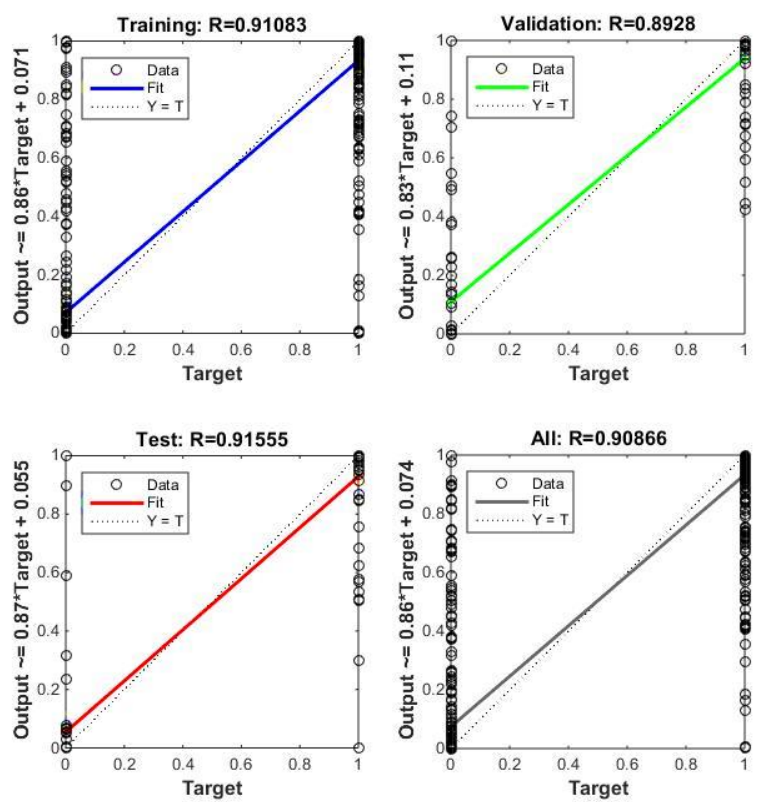

Gambar 9: Gambar Regresi Pelatihan Gradient Polak Ribiere
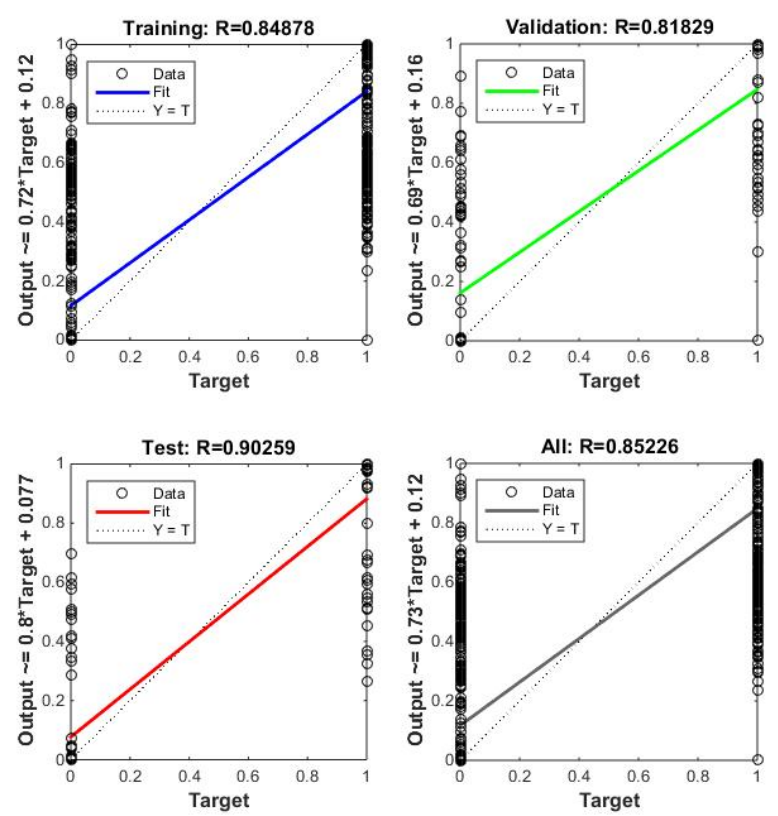

Gambar 10: Gambar Regresi Pelatihan Gradient Discent

p-ISSN:1693 - 2951; e-ISSN: 2503-2372 
Pada Gambar 9 dan Gambar 10 di atas di bawah ini nampak bahwa dengan iterasi pelatihan yang sama Regresi Gradient Polak Ribiere lebih baik dibandingkan dengan Regresi Gradient Discent, hal ini nampak dari nilai regresi yag di peroleh dengan Gradient Polak Ribiere > Regresi Gradient Discent.

\section{2) Analisis Kinerja Tahap Pengujian:}

Pada tahap pengujian akan di ujikan 200 data uji. Gambar 11 adalah salah satu sampel bit sinyal termodulasi yang telah di bangkitkan secara acak sebagai data uji.

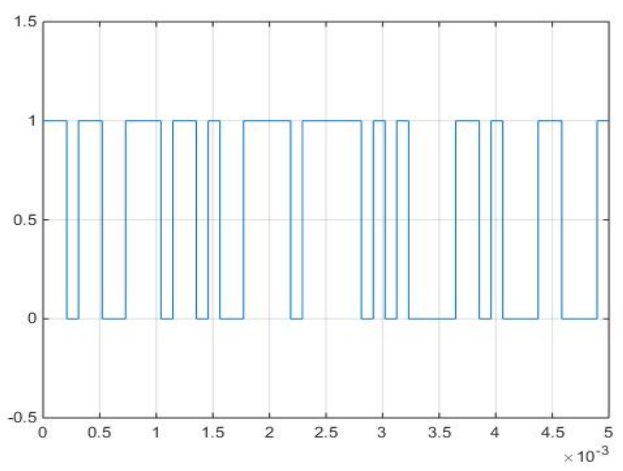

Gambar 11: Gambar Bit Sinyal Data Uji

Sinyal termodulasi yang telah dibangkitkan tersebut kemudian akan di ekstrak dengan menggunakan pendekatan statistik untuk mendapatkan nilai karakteristiknya. Dalam pengujian ini menggunkan pasangan fitur dengan mengacu pada Tabel 5 berikut .

TABEL 5

TABEL PASANGAN FITUR PENGUJIAN

\begin{tabular}{|c|c|c|}
\hline No & Kode Fitur & Keterangan \\
\hline 1 & $1 ; 2 ; 3 ; 4$ & Mean, Varian, Kurtosis, Skewness \\
\hline 2 & $1 ; 2 ; 3$ & Mean, Varian, Kurtosis \\
\hline 3 & $1 ; 2 ; 4$ & Mean, Varian, Skewness \\
\hline 4 & $2 ; 3$ & Varian, Kurtosis \\
\hline 5 & $1 ; 3$ & Mean, Kurtosis \\
\hline 6 & $2 ; 4$ & Varian, Skewness \\
\hline 7 & $1 ; 2$ & Mean, Varian \\
\hline 8 & $3 ; 4$ & Kurtosis, Skewness \\
\hline
\end{tabular}

Hasil dari pengujian data uji pada Gambar 11 di atas dengan nilai Akurasi hasil pembelajaran sebesar 83,70 dan laju error sebesar 16,21 dengan mengacu pasangan fitur pada Tabel 5 diatas diperoleh hasil sesuai dengan Tabel 6 berikut.

TABEL 6 HASIL PENGUJIAN

\begin{tabular}{|c|c|c|c|c|c|}
\hline No & Fitur & y1 & y2 & y3 & Keterangan \\
\hline 1 & $1 ; 2 ; 3 ; 4$ & 0 & 0 & 1 & Tidak Dikenal \\
\hline 2 & $1 ; 2 ; 3$ & 0 & 0 & 1 & Dikenal \\
\hline 3 & $1 ; 2 ; 4$ & 0 & 0 & 1 & Dikenal \\
\hline 4 & $2 ; 3$ & 0 & 0 & 1 & Tidak Dikenal \\
\hline 5 & $1 ; 3$ & 0 & 0 & 1 & Tidak Dikenal \\
\hline 6 & $2 ; 4$ & 0 & 0 & 1 & Tidak Dikenal \\
\hline 7 & $1 ; 2$ & 0 & 0 & 1 & Tidak Dikenal \\
\hline
\end{tabular}

\begin{tabular}{|c|c|c|c|c|c|}
8 & $3 ; 4$ & 0 & 0 & 1 & Tidak Dikenal \\
\hline 9 & $1 ; 2 ; 3 ; 4$ & 0 & 1 & 0 & Tidak Dikenal \\
\hline 10 & $1 ; 2 ; 3$ & 0 & 1 & 0 & Tidak Sesuai \\
\hline 11 & $1 ; 2 ; 4$ & 0 & 1 & 0 & Tidak Dikenal \\
\hline 12 & $2 ; 3$ & 0 & 1 & 0 & Tidak Dikenal \\
\hline 13 & $1 ; 3$ & 0 & 1 & 0 & Tidak Dikenal \\
\hline 14 & $2 ; 4$ & 0 & 1 & 0 & Tidak Dikenal \\
\hline 15 & $1 ; 2$ & 0 & 1 & 0 & Tidak Dikenal \\
\hline 16 & $3 ; 4$ & 0 & 1 & 0 & Tidak Dikenal \\
\hline 17 & $1 ; 2 ; 3 ; 4$ & 0 & 1 & 1 & Tidak Dikenal \\
\hline 18 & $1 ; 2 ; 3$ & 0 & 1 & 1 & Tidak Sesuai \\
\hline 19 & $1 ; 2 ; 4$ & 0 & 1 & 1 & Tidak Dikenal \\
\hline 20 & $2 ; 3$ & 0 & 1 & 1 & Tidak Dikenal \\
\hline
\end{tabular}

Dari Tabel 6 di atas diketahui bahwa kemampuan jaringan backpropagation dalam mendeteksi tie modulasi dengan sinyal data sesuai dengan Gambar 11 masih tergolong sangat rendah. Sehingga masih perlu dilakukan pelatihan terhadap jaringan hingga jaringan mampu meningkatkan kemampuannya dalam mendeteksi tipe modulasi dengan baik.

\section{KESIMPULAN}

Paper ini telah memaparkan implementasi metode Conjugate Gradient Polak Ribiere-Backpropagation untuk segmentasi tipe modulasi QPSK,16-QAM dan 64-QAM berdasarkan ciri statistik. Hasil analisis menunjukkan bahwa metode Conjugate Gradient Polak Ribiere mampu mengenali tipe modulasi dengan efisiensi pembelajaran jauh lebih baik saat dilakukan komparasi dengan Gradient Discent, hal ini nampak dari nilai regresi yang dihasilkan dengan Conjugate Gradient Polak Rebiere > Gradient Discent

\section{REFERENSI}

[1] Yeste-Ojeda, Omar, Jesus Grajal, Victor Iglesias, "Automatic Modulation Classifier For Military Applications", Signal Processing Conference, Barcelona, pp.1814-1818, 2011.

[2] M.H Valipour, M.Mehdi, "Automatic Digital Modulation Recognition in Presentace of Noise Using SVM and PSO ", 6'th International Symposium on Telecommunication (IST 2012),2012.

[3] Afif Dias Pambudi, Suhartono T, Heroe Wijanto, "Deteksi Automatis Skema Modulasi Sinyal OFDM Menggunakan Ciri Statistik dan Klasifikasi PSO”, Jurnal ELKOMIKA, 2015.

[4] Aditya D P, Haroe W, Desti M S, "Pendeteksi Tipe Modulasi Menggunakan Algoritma Genetika dan Jaringan Syaraf Tiruan Pada Rekognisi Modulasi Otomatis", SESINDO, 2013.

[5] Anto S.N, Arief B.W, Dwi Handoko, "Support Vector Machine dan Aplikasinya Dalam Bioinformatika ", Kuliah Umum Ilmu Komputer.com, 2003.

[6] Chih-Wei Hsu, Chih-Jen Lin, "A Comparison of Methods for Multiclass Support Vector Machines", IEEE Transaction on Neural Networks, Vol.13, No.2, pp.415-425, March 2002.

[7] Azminuddin I.S Azis, Vincent Suharto, H.Himawan,"Model MultiClass SVM menggunakan strategi 1V1 Untuk Klasifikasi WallFollowing Robot Navigation Data", Jurnal Teknologi Informasi CyberKU, Volume 13 Nomor 2, 2017.

[8] Shewchuk, Jonathan R,"An Intoduction to the Conjugate Gradient Method Without the Agonizing Pain", Pittsburgh, School of Computer Science Carnegie Mellon University, 1994.

[9] M.J.D Powel, "Restart Procedures for the Conjugate Gradient Method", Math programming, vol.12, no.1, pp.241-254,1977.

[10] Untari N.Wisesty, Adiwijaya, Tjokorda Agung B.W, "Algoritma Conjugate Gradient Polak Ribiere Untuk Meningkatkan Performasi Backpropagation Pada Sistem Prediksi Temperatur Udara", Jurnal Penelitian dan Pengembangan Telekomunikasi Vol.15, 2010. 